\title{
SIMILARITIES BETWEEN SUSTAINABLE DEVELOPMENT AND COMPETITIVENESS OF THE REGIONS - THEORETICAL APPROACH
}

\begin{abstract}
Regional development is associated with a number of factors. It seems nowadays that there are two main approaches to that issue: necessity of increasing the competitiveness on the one hand, and aiming at the sustainable development on the other. Some authors belive that pursuit to improve competitiveness excludes sustainable development, others do not share the opinion. However, it seems to be important not to oppose these two ideas each other but to unite them. Recently, these two approaches: endeavour to improve the competitiveness and implemenentation of the sustainable development's principles into the practice have been used more and more combined as an idea of sustainable competitiveness. This paper aims to present an analysis of the chosen definitions and of the main terms describing competitiveness. It also discusses goals and definitions of sustainable development and other terms related to that concept in order to to find similarities between these two ideas, particulary at the regional level. Similarattributes for competitiveness and sustainability were identified as following: improvement of the quality of life and economic development (in case of competitiveness only in the material field), implementation of ecological innovations and significant role of local and regional authorities. These two concepts are also strictly related to idea of regional resilience. Both, competitive and sustainable regions must be resilient.

The article is divided into three main parts. The first presents definitions and factors of regional competitiveness. This is followed by a presentation of definitions and components of sustainable development. The third part then looks similarities between regional competitiveness and sustainability.
\end{abstract}

Keywords: region, sustainable development, competitiveness, similarities, sustainable competitiveness.

\section{INTRODUCTION}

Today, among the many aims of socio-economic development, one can count the desire to improve competitiveness and sustainable development ${ }^{2}$, that is, to adapt both to the "environmental' conditions. Some authors maintain that these approaches are mutually exclusive, although many publications show that they are increasingly combined with one another. For example, already in the Lisbon strategy, the European Union (EU) was to have the most competitive and dynamic economy in the world, to attain through respecting the

1 Dr Hanna Kruk, Katedra Ekonomii i Polityki Gospodarczej, Wydział Przedsiębiorczości i Towaroznawstwa, Akademia Morska w Gdyni; tel. + 4858 5586544; e-mail: h.kruk@wpit.am.gdynia.pl.

2 In the literature, the concepts of sustainability and the concept of sustainable development are often used interchangeably. Some authors believe that the sustainability has replaced sustainable development. 
principles of sustainable development concepts and measures for the protection and preservation of the environment ${ }^{3}$. Equally, the "Europe 2020" strategy aimed at further deepening of the relationship between increasing competitiveness and sustainable development ${ }^{4}$.

On the whole, the concept of sustainable competitiveness is often use in the literature and other publications, linking at different levels (macro, meso and micro) the improvement of competitiveness with the ideas of making economy more 'green'. This article attempts to find similarities between regional competitiveness and sustainable development and seeks to define the concept of sustainable competitiveness of regions.

\section{COMPETITIVENESS OF THE REGION}

Definitions of competitiveness were formulated a number of times, which happened mostly in the context of businesses or national economies. Competitiveness of regions however has relatively rarely been defined. Scholars who deal with this issue often do so by referring competitiveness to the macro- and microeconomic levels. In the latter case, the competitiveness of regions is regarded as the aggregate competitiveness of enterprises, which is often understood as their productivity (transfer of assumptions about competitiveness from the microeconomic to the mezzo-economic level). By contrast, in the macroeconomic approach, regional competitiveness is often seen as a derivative of the national competitiveness, which usually manifests itself by taking into account the national wellfare and country respective population well-being (measured by income per capita), employment levels and favourable environment ${ }^{5}$.

According to the definition of the European Commission, regional competitiveness means "the ability to produce goods and services which pass the test of international markets, while at the same time maintaining high and sustainable levels of income or, more generally, the ability of (regions) to generate, while being exposed to external competition, relatively high income and employment levels"6.

$Đ$. Borozan remarks that there is another division of the definition of regional competitiveness: in some definitions attention is drawn to outcome or to the factors involved in achieving or increasing the level of competitiveness, e.g. knowledge, crealitivy, innovativeness, social networks, historical and cultural background, etc. ${ }^{7}$. R. Martin and P. Tyler believe that regions compete with each other to attract investment capital, new technologies

${ }^{3}$ B. Johansson, C. Karlsson, M. Backman, P. Juusola, The Lisbon Agenda from 2000 to 2010, CESIS Electronic Working Paper Series, Paper 2007, No. 106, pp. 13-15.

${ }^{4}$ A. Balkyte, M. Tvaronavičienè, Perception of competitiveness in the context of sustainable development: Facets of 'sustainable competitiveness, "Journal of Business Economics and Management" 2010, 11 (2), pp. 341-342.

${ }^{5}$ P. Annoni, K. Kozovska, EU Regional Competitivness Index, RCI 2010, European Commission, Joint Research Centre, Luxembourg 2010, p. 1; L. Vrtěnová, Evaluation of factors of regional competitiveness [in:] Third Central European Conference in Regional Science. International Conference Proceedings, (Eds.) M. Buček, R. Capell, O. Hudec, P. Nijkamp, Košice 2009, p. 1405; $Đ$. Borozan, Regional competitiveness: some conceptual issues and policy implications [in:] Interdisciplinary Management Research IV. (Eds.) D. Barković, B. Runzheimer, Osijek - Pforzheim 2008, pp. 52-53, 56-58.

${ }^{6} \mathrm{cf}$. L. Budd, A. Hirmis, Conceptual framework for regional competitiveness, "Regional Studies" 2004, 38(9), p. 1022.

${ }^{7}$ Đ. Borozan, Regional competitiveness..., p. 60. 
and knowledge as well as human resources (skilled workers and entrepreneurs) ${ }^{8}$. Similar definition has been elaborated by $\mathrm{H}$. Godlewska: regional competitiveness is a group of attributes describing attractiveness, ability to compete and capacity for absorbing new technologies, knowledge, etc. ${ }^{9}$. A. Klasik defines competitiveness as a result of region's attractiveness, advantages of its productivity and its capacity to export ${ }^{10}$. D. Waldziński believes that comeptitiveness is related to the ability of effective use of reional resources that increase its attractiveness and, in the end, improves the copmetitiveness itself ${ }^{11}$. R. Brol for his part presents the triad of economic development: innovativeness, competitiveness and regional development ${ }^{12}$.

Most authors maintain that the competitiveness of regions (or cities) is closely linked to the ability of the local economy and the local community to improve the standard of human living $^{13}$. I. Turok assumes that regional competitiveness is a result of three components and the relationship between them: first, the ability of local businesses to sell at external markets what they have produced; second, the value of these products and the efficiency of their production and, third, the ability to use the resources of the regions, including the human, natural and capital resources ${ }^{14}$.

The analysis of selected definitions of competitiveness enables us to dissect their main components mentioned by various authors (see Table 1 ). In table 1 , the columns are numbered from 1 to 8 :

1 - the use of regional resources determining regional potential;

2 - the ability to absorb capital, technology, know-how, etc. from outside;

3 - the production of goods and (or) an increase in productivity;

4 - the increase of the level of income in the population (welfare);

5 - the maintenance of a relatively high level of employment;

6 - a set of characteristics which determine the attractiveness of the regions, the use of assets (strengths), creating the image of regions;

7 - the creation of conditions for the development of entrepreneurship;

8 - the ability to international competition (market share, export strength);

8 cf. L. Budd, A. Hirmis, Conceptual framework..., p. 1021.

9 H. Godlewska, Lokalizacja działalności gospodarczej, Warszawa 2001, p. 27.

10 A. Klasik, Strategie konkurencyjne polskich regionów [in:] Nowe kierunki badawcze w regionalistyce. Nowe doświadczenia polityki regionalnej, Ed. R. Domański, KPZK PAN, Biuletyn 2003, z. 204, p. 63.

11 D. Waldziński, Polityka regionalna $w$ Polsce $w$ procesie przemian kulturowo-cywilizacyjnych. Zarys problemu, Olsztyn 2005, p. 45-46.

${ }^{12}$ R. Brol, Innowacyjność regionu $w$ teorii i praktyce [in:] Problemy rozwoju regionalnego, Eds. R. Brol, A. Raszkowski, Prace Naukowe Uniwersytetu Ekonomicznego we Wrocławiu, 180, Wrocław 2011, p. 16.

${ }_{13}$ S. Singhal, S. McGreal, J. Berry, An evaluative model for city competitiveness: Application to UK Cities, "Land Use Policy" 2013, 30, p. 214; P. Annoni, K. Kozovska, EU Regional Competitivness Index. RCI 2010..., p. 2; Đ. Borozan, Regional competitiveness: some conceptual issues and policy implications..., p. 58; H. Kruk, Przyrodnicza konkurencyjność regionów. Toruń 2010, p. 73.

${ }^{14}$ I. Turok, Cities, regions and competitiveness, "Regional Studies" 2004, 38(9), p. 1070. 
Table 1. Frequently mentioned dimensions of regional competitiveness - selected definitions

\begin{tabular}{|c|c|c|c|c|c|c|c|c|c|}
\hline Author & 1 & 2 & 3 & 4 & 5 & 6 & 7 & 8 & Source \\
\hline $\begin{array}{l}\text { S.A. Beru- } \\
\text { men }\end{array}$ & + & - & + & - & - & + & + & + & Berumen 2005 \\
\hline Đ. Borozan, & - & + & - & + & - & + & - & - & Borozan 2008 \\
\hline $\begin{array}{l}\text { L. Dijkstra, } \\
\text { P. Annoni, } \\
\text { K. Kozlov- } \\
\text { ska }\end{array}$ & - & - & - & + & - & + & + & - & $\begin{array}{l}\text { Annoni, Dijks- } \\
\text { tra, Gargano } \\
2017\end{array}$ \\
\hline $\begin{array}{l}\text { P. Góralski, } \\
\text { M. Lazarek }\end{array}$ & - & + & - & + & - & + & + & - & Koszel 2016 \\
\hline $\begin{array}{l}\text { J. Huovari, } \\
\text { A. Kan- } \\
\text { gasharju, } \\
\text { A. Alanen }\end{array}$ & - & + & - & + & - & - & + & - & $\begin{array}{l}\text { Houvari, Kan- } \\
\text { gasharju, } \\
\text { Alanen } 2001\end{array}$ \\
\hline A. Klasik & + & - & + & - & - & + & - & + & Klasik 2003 \\
\hline R.L. Martin & - & - & + & + & - & - & - & + & Vrtěnová 2009 \\
\hline $\begin{array}{l}\text { R.L. Martin, } \\
\text { P. Tyler }\end{array}$ & - & + & - & + & - & - & - & + & $\begin{array}{l}\text { Budd, Hirmis } \\
2004\end{array}$ \\
\hline $\begin{array}{l}\text { J. Meyer- } \\
\text { Stamer }\end{array}$ & - & - & + & + & - & - & - & - & $\begin{array}{l}\text { Annoni, } \\
\text { Kozovska } \\
2010\end{array}$ \\
\hline OECD & - & - & + & + & - & - & - & + & $\begin{array}{l}\text { Balkytė, } \\
\text { Tvaronavičiené } \\
\text { 2010; Gryszel } \\
2017\end{array}$ \\
\hline M.E. Porter & + & + & + & - & - & + & + & - & Porter 2008 \\
\hline $\begin{array}{l}\text { Report of } \\
\text { the Euro- } \\
\text { pean Com- } \\
\text { mission }\end{array}$ & - & - & + & + & + & - & - & + & $\begin{array}{l}\text { Budd, Hirmis } \\
\text { 2004; Lengyel } \\
2016\end{array}$ \\
\hline M. Storper & - & + & - & + & - & - & - & + & Borozan 2008 \\
\hline I. Turok & + & - & + & - & - & - & - & + & Turok 2004 \\
\hline $\begin{array}{l}\text { D. } \\
\text { Twardowski }\end{array}$ & - & - & - & + & - & - & + & & Koszel 2016 \\
\hline M. Viturka & + & - & + & - & - & - & - & - & Vrtěnová 2009 \\
\hline
\end{tabular}

The most frequent elements in the definitions of regional competitiveness are: productivity; improved standards of living (as measured by an increase of income); the competition at the international level (presence in foreign markets, including the production of such goods in the region that can cope with international competition); the ability to attract knowledge, technology, investments from outside; and the use of resources and capital (including social one) existent in the region. Sometimes the need to use the strengths of the region ${ }^{15}$ and creating its positive image are stressed.

The authors of the analyzed definitions of competitiveness' factors most often refer to such factors as human, social and cultural capital, knowledge and technology. They do so

\footnotetext{
${ }^{15}$ It can be assumed that some scholars considered it as obvious.
} 
while marginalizing at the same time aspects of the natural ${ }^{16}$. It is generally assumed that the development of the regions and their competitiveness are mostly affected by those factors that are "active", i.e. those assets that are most often used ${ }^{17}$.

\section{SUSTAINABLE DEVELOPMENT AT THE REGIONAL LEVEL}

The sustainable development, just as the concept of competitiveness, was also defined at several occasions, however in this case it does not seem to distinguish between the micro, mezzo-, and macro levels ${ }^{18}$. It is assumed that sustainable development is often being linked to the ecologization ("greening") of the economy, i.e. to running economy in such a way as to satisfy human needs and at the same time to adapt it to respecting the environmental limits (limited natural resources and the capacity of ecosystems). In general, three main dimensions of sustainable development are referred to: economic, ecological (environmental) and social (socio-cultural) all of which should be equal and integrated ${ }^{19}$.

Most often, however, the literature quotes the definition provided in the so-called Report of the Brundtland Commission. According to this report, it is assumed that "sustainable development meets the needs of the present generation without compromising the ability of future generations to meet their own needs" ${ }^{20}$. D. Pearce, A. Markandya and E.B. Barbier for their part maintain that "sustainable development involves a social and economic system which ensures that these goals are sustained, i.e. that real incomes rise, that educational standards increase, that the health of the nation improves, that the general quality of life is advanced" 21 .

A number of other authors emphasize the need for a holistic and integrated approach to the principles of sustainable development. Table 2 shows the main elements mentioned in some definitions of sustainable development. The columns are numbered from 1 to 8 : 1 - improving the quality of life (living conditions, to achieve a high standard of living); 2 - preservation of inter- and intra-generational justice;

${ }^{16}$ F.J. Ayala-Carcedo, M.R. y Gonzáles-Barros, Economic underdevelopment and sustainable development in the world: conditioning factors, problems and opportunities, "Environment, Development and Sustainability" 2005, 7, p. 102.

${ }^{17}$ H. Kruk, D. Waldziński, Rozwój zrównoważony i konkurencyjność regionów - rozważania teoretyczne [in:] Problemy rozwoju regionalnego, ed. R. Brol, Prace Naukowe UE we Wrocławiu, Wrocław 2010, 110, pp. 88-89.

18 This term refers rather to the countries and regions, but in the literature the authors present the issues of sustainable production and consumption.

19 S.A. Adesola, Overcoming the challanges of sustainable development through science and technology education, "Journal of Educational and Social Research" 2012, 2(7), pp. 12-13; B. Piontek, Koncepcja rozwoju zrównoważonego i trwatego Polski, Warszawa 2002, pp. 15-27, 63; H. Rogall, Ekonomia zrównoważonego rozwoju. Teoria i praktyka, Poznań 2010, s. 44; J.A. Elliott, An introduction to sustainable development, London-New York 2013, pp. 20-21.

${ }^{20} \mathrm{cf}$. M. Keiner, Re-emphasizing sustainable development - the concept of 'evolutionability', "Environment, "Development and Sustainability" 2004, 6, p. 380.

${ }^{21} \mathrm{cf}$. M. Christen, S. Schmidt, A formal framework for conceptions of sustainability - a theoretical contribution to the discourse in sustainable development, "Sustainable Development" 2012, 20(6), p. 401. 
3 - reducing the impact on the environment (environmental care), preserving (protection) of the natural environment (in terms of quality and quantity), rational use of the natural resources;

4 - the proportions between dimensions: ecological, economic and social;

5 - social participation;

6 - meeting the public needs (social, economic, environmental etc.);

7 - taking into account the natural capacity (absorption) of the environment and the functioning of ecosystems (greening of the economy);

8 - sustainable development (or growth) the economy, productivity, eco-efficiency.

Table 2. Frequently mentioned dimensions of sustainable development - selected definitions

\begin{tabular}{|l|c|c|c|c|c|c|c|c|l|}
\hline \multicolumn{1}{|c|}{ Author } & $\mathbf{1}$ & $\mathbf{2}$ & $\mathbf{3}$ & $\mathbf{4}$ & $\mathbf{5}$ & $\mathbf{6}$ & $\mathbf{7}$ & $\mathbf{8}$ & \multicolumn{1}{|c|}{ Source } \\
\hline S. Bell, S. Morse & + & - & + & + & - & - & - & + & $\begin{array}{l}\text { Moles, Foley, Morrissey, } \\
\text { O'Regan 2008 }\end{array}$ \\
\hline K. Dubel & - & + & + & - & - & + & - & - & Piontek 2002 \\
\hline D. Gibbs & + & + & + & - & + & - & - & - & Gibbs 2010 \\
\hline $\begin{array}{l}\text { S. Imran, K. } \\
\text { Alam, N. Beau- } \\
\text { mont }\end{array}$ & + & + & - & - & - & - & + & - & $\begin{array}{l}\text { Imran, Alam,Beaumont } \\
2014\end{array}$ \\
\hline $\begin{array}{l}\text { W.J. Mckinney } \\
\text { H.H. Hill }\end{array}$ & - & + & + & - & - & - & - & + & Mckinney, Hill 2000 \\
\hline E. Mieszajkina & + & + & + & - & - & + & - & - & Mieszajkina 2016 \\
\hline T. Miller & + & + & + & - & - & + & - & - & Fisher, Rucki 2017 \\
\hline MONET & + & + & + & - & - & - & - & - & Keiner 2004 \\
\hline $\begin{array}{l}\text { D. Pearce, A. } \\
\text { Markandya, E.B. } \\
\text { Barbier }\end{array}$ & + & - & - & - & - & - & - & + & Christen, Schmidt 2012 \\
\hline F. Piontek & + & + & - & + & - & - & - & - & Piontek 2002 \\
\hline B. Poskrobko & + & - & - & - & - & - & + & + & Piontek 2002 \\
\hline $\begin{array}{l}\text { Report of } \\
\text { Brundtland } \\
\text { Commission }\end{array}$ & - & + & - & - & - & + & - & + & Keiner 2004 \\
\hline J. Śleszyński & + & - & - & - & - & - & + & - & Piontek 2002 \\
\hline T. Żylicz & - & + & - & - & - & + & - & - & Piontek 2002 \\
\hline
\end{tabular}

In the analyzed definitions of sustainable development, the principle of justice and the broadly conceived improvement of the quality of life are the most often mentioned. One can thus conclude that the social goals are dominant. In the case of the environmental dimension in the definition of development, the issues of ecosystems stability and reduction of the negative impact of human activities on the environment are taken into account.

Most definitions refer to sustainable development (or sustainability) in more general terms. In the literature, however, one can (though rarely) find references to sustainable development at the regional level. According to M.L.M. Graymore, "regional sustainability requires the human population to live within the limits of the region's supporting systems 
(social, economic and ecosystem) Ensuring equitable sharing of resources and opportunities for this and future generations in the region" 22 .

One of the main goals of sustainable development can be here a lasting improvement in the quality of life in the region while preserving its natural and cultural values. With regard to sustainable development, the literature has not really identified its determinants. In the case of regions, it can be assumed that sustainability of such a development is influenced by internal and external factors affecting social, economic and environmental aspects of a region.

\section{SUSTAINABLE DEVELOPMENT AND COMPETITIVENESS OF THE REGIONS - SIMILARITIES}

As mentioned in the introduction, in relation to the EU countries the increased competitiveness of the EU as an entire integration group and individual national economies is linked to the implementation of sustainable development principles into the business practice. The concept of sustainable competitiveness, which is increasingly used in the literature, originates from the combination of both these theories.

It is commonly believed that efforts to protect and preserve the natural environment may result in a reduction of competitiveness at the micro-, mezzo-, and macro-level on the one hand, while economic growth (which is linked to competitiveness) causes environmental degradation and depletion of (at least some) natural resources, on the other. The latter contradicts the environmental Kuznets' curve. Its line illustrates the correspondence between the per capita income (or GDP growth) and the level of environmental degradation. The growth is initially combined with an increase in environmental pollution, whereas after reaching a maximum, a further increase in growth happens with decreasing environmental degradation - which is why, metaphorically speaking, the curve has the shape of an inverted "U"23.

Although M.E. Porter and C. van der Linde also draw attention to the fact that in general opinion the pursuit of sustainable development reduces the competitiveness of economic entities (due to increased costs related to the protection of environment, and more specifically - the cost of reducing pollution), they however do not agree with this opinion. In fact, they maintain that environmental quality standards create a stimulus to innovative developments, which in turn can reduce production costs and lead to better quality of products, which for its part increases their competitiveness. The benefits of increased innovation (including the increase in productivity) as the effect of environmental regulations (the aim of which is to reduce the negative impact of economy on the environment) are, according to the authors, underestimated by many researchers ${ }^{24}$. So, the measures to reduce pollution may not lead to a decreased competitiveness but rather to its increase. What follows from this assumption is that waste and pollution generated in the production process indicate that

${ }^{22}$ M.L.M. Graymore, N.G. Sipe, R.E. Rickson, Regional sustainability: How useful are current tools of sustainability assessment at the regional scale?, "Ecological Economics" 2008, 67, pp. 262-263.

${ }^{23}$ S. Borghesi, A. Vercelli, Global sustainability. Social and environmental conditions, HampshireNew York 2008, pp. 17-19.

${ }^{24}$ What results from the dominance of the static, and not dynamic, approach. The implication is that, according to Porter and van der Linde, the top-down regulations may limit innovation processes. 
resources were used inefficiently. According to this idea, exactly the rational, cost-effective and productive use of resources is the key element of competitiveness. Such an approach links the competitiveness with environmental aspects ${ }^{25}$.

This approach leads to the following statements:

1) the pursuit of sustainable development does not necessarily exclude the competitiveness,

2) the common element contributing to both the competitiveness and to achieving the objectives of sustainable development is innovation, more precisely, the so-called eco-innovation.

The latter term is quite broad and can include, according to F. Bosshard, all the ecoinnovations that lead to the "creation of new, competitively priced goods (products and services), processes, systemic solutions and procedures aiming at meeting human needs and improving the quality of life by minimizing the consumption of natural resources (raw materials, including energy and space), - all throughout the life cycle of products - as measured by production per unit by assuming a minimum emission of toxic substances" 26 . It can thus be assumed that it is about innovations that minimize the negative impact of economy on the environment and that lead to better, more efficient use of resources (and thus to improved competitiveness). This concept includes the so-called environmental technologies, environmental management systems, alternative production systems, as well as production methods and new products that are conducive to environment ${ }^{27}$.

The analysis of the definition of sustainable development and competitiveness points to another common element in both theories: i.e. improving the standard of living of the inhabitants in the region ${ }^{28}$. In the case of competitiveness, it is said to improve the income (and therefore the emphasis is placed on the material aspect), and in relation to sustainable development, the immaterial components of quality of life are highlighted. The latter can be presented in an objective $\mathrm{e}^{29}$ or subjective ${ }^{30}$ way. The quality of life is also linked to the

${ }_{25}$ M.E. Porter, C. van der Linde, Green and competitive: ending the stalemate, "Harvard Business Review" 1995, 73(5), pp. 120-122, 133-134.

${ }^{26} \mathrm{cf}$. A. Reid, M. Miedzinski, Sectoral innovation watch in Europe. Ecoinnovation, Final report, Systematic Eco-Innovation Report, Europe Innova, Technopolis Group, Brussels 2008, p. 3.

${ }_{27}$ R. Kemp, Measuring eco-innovation, Research Brief 1, United Nations University, 2008, p. 3; M. Marczewska, Źródła i mechanizmy powstawania ekoinnowacji w przedsiębiorstwach dostawcach technologii środowiskowych, Warszawa 2016, s. 43, 49-51; M. Ziółko, J. Mróz, Wpływ ekoinnowacyjności na wzrost konkurencyjności przedsiębiorstw, Acta Universitatis Nicolai Copernici, 2015, XLII (1), pp. 75-76; L. Woźniak, Ekoinnowacyjność w gospodarce żywnościowej [in:] Ekoinnowacyjność dziś i jutro - wyzwania, bariery rozwoju oraz instrumenty wsparcia, Eds. L. Woźniak, J. Strojny, E. Wojnicka. Warszawa 2010, pp. 161-164; T. Dyllick, Z. Rost, Towards true product sustainability, "Journal of Cleaner Production" 2017, 162, pp. 348-350; E. Mieszajkina, Ecological entrepreneurship and sustainable development, "Problemy Ekorozwoju - Problems of Sustainable Development" 2016, 12(1), p. 167.

${ }_{28}$ S. Ručinská, P. Paška, Measuring regional competitiveness, Acta oeconomica cassoviensia 1 (Vol. II, No. 1), 2009, p. 7.

${ }^{29}$ It is measured by e.g. using the GDP per capita, Human Development Index and by using similar indicators.

${ }^{30}$ Seen from the perspective of a human being, and based on its individual needs and perceptions. 
issue of meeting the diverse needs of people. Meeting those needs affects the subjective perception about the welfare system, and thus the quality of life of people ${ }^{31}$.

The pursuit of sustainable development does not preclude economic growth; it is however based on somewhat different grounds. One can assume that this is due to the change of the classical approach "to produce more, and consume more" into at least one "to produce more or the same, but consume less", and an approach combined with a radical change in the system into one "to produce less, consume less, but produce something else" 32 . Some scholars talk about a sustainable growth that indicates a strategy for economic development based on the principles of sustainable development, more efficient use of resources (including natural resources ${ }^{33}$ ), a fair distribution of costs and benefits and the development of technologies conducive to environment (so-called green technologies). Such an increase is also related to the construction of civil society and participation of local communities in decision making. Sustainable growth is supposed to lead to the reduction of the negative impact on the environment, as well as to the improvement of competitiveness ${ }^{34}$.

Another element linking the concepts discussed above is the significant role of local and regional authorities: mostly in the quest for increased competitiveness, to improve the quality of life and to implement the objectives of sustainable development. It is the policy of such authorities that shapes among other things the direction and strategy of development, the ability to raise funds from external sources of funding and the support for entrepreneurship, innovation, maintenance of infrastructure and rational use of land in the region, provision of public goods (education, health care, social assistance, order, etc.), preservation of cultural heritage and natural heritage, promotion of the region and its values ${ }^{35}$.

Both contepts, the regional competitiveness and the sustainable development relate to the idea of regional resilience. The term originates from natural sciences and relates to the capacity of organisms or ecosystems to adapt and develop under disadvantageous conditions (fexibility and stability) and to return to its quilibrium state ${ }^{36}$. The idea of resilience has been adapted by economic sciences as ability of regions to predict distrubances, recover

${ }^{31}$ R. Costanza, B. Fisher, S. Ali, C. Beer, L. Bond, R. Boumans, N.L. Danigelis, J. Dickinson, C. Elliot, J. Farley, D. Elliott Gayer, L. MacDonald Glenn, T. Hudspeth, D. Mahoney, L. McCahill, B. McIntosh, B. Reed, S. Abu Turab Rizvi, D.M. Rizzo, T. Simpatico, R. Snapp, Quality of life: An approach integrating opportunieties, human needs and subjective well-being, "Ecological Economics" 2007, 61, pp. 268-269, 273; T. Borys, Jakość życia a systemy wartości [in:] Uwarunkowania jakości życia w społeczeństwie informacyjnym, Ed. E. Skrzypek, Lublin 2007, pp. 215-218; T. Borys, Typologia jakości życia i pomiar statystyczny, "Wiadomości Statystyczne" 2015, 7, pp. 2, 11-13; O. Stanaszek, Badanie jakości życia w Polsce [in:] Gospodarka regionalna w teorii i praktyce, Eds. E. Sobczak, D. Głuszczuk, M. Obrębalski, Prace Naukowe Uniwersytetu Ekonomicznego we Wrocławiu, Wrocław 2015, 392, pp. 102-103.

32 A. Ginsbert-Gebert, Ekologiczne uwarunkowania spoteczno-ekonomicznego rozwoju Polski, Warszawa 1990, s. 22-25.

${ }^{33}$ Some authors stress the need to limit the use of non-renewable resources, considering its permanent use as a sign of imbalance.

34 A. Balkytè, M. Tvaronavičienè, Perception of competitiveness..., pp. 356-357.

${ }_{35}^{35}$ H. Kruk, Przyrodnicza konkurencyjność...., s. 171-173.

${ }^{36}$ S. Christopherson, J. Michie, P. Tyler, Regional resilience: theoretical and empirical perspectives, "Cambridge Journal of Regions, Economy and Society" 2010, 3, p. 3; F. Brand, Critical natural capital revisited: Ecological resilience and sustainable development, "Ecological Economics" 2009, 68, p. 606. 
after shocks and return to preceding growth paths (i.e. level of employment and production), or to adapt to changing conditions or shocks (economic crises, neutal diseasters, etc.) and, if the process fails, to maintain or to re-organise its structures ${ }^{37}$. R. Hudson links resilience to sustainable development: "Now there is an increasingly strong imperative to move towards more self-contained and sustainable models of regional development, to create more resilient regions by maximising intra-regional flows and connections (in part to help close materials loops) and by moving towards environmentally less damaging processes of production, exchange and consumption" ${ }^{38}$. Similar idea is presented by J. Fisjer and K. Rucki ${ }^{39}$. In turn, G. Bristow shows similarities between competitiveness and resilience at the level of regions ${ }^{40}$. It can be assumed that both competitive and sustainable regions must be resilient to achieve the set goals of development.

Eventually, both concepts of sustainable development as well as of regional competitiveness share a number of common elements (Figure 1).

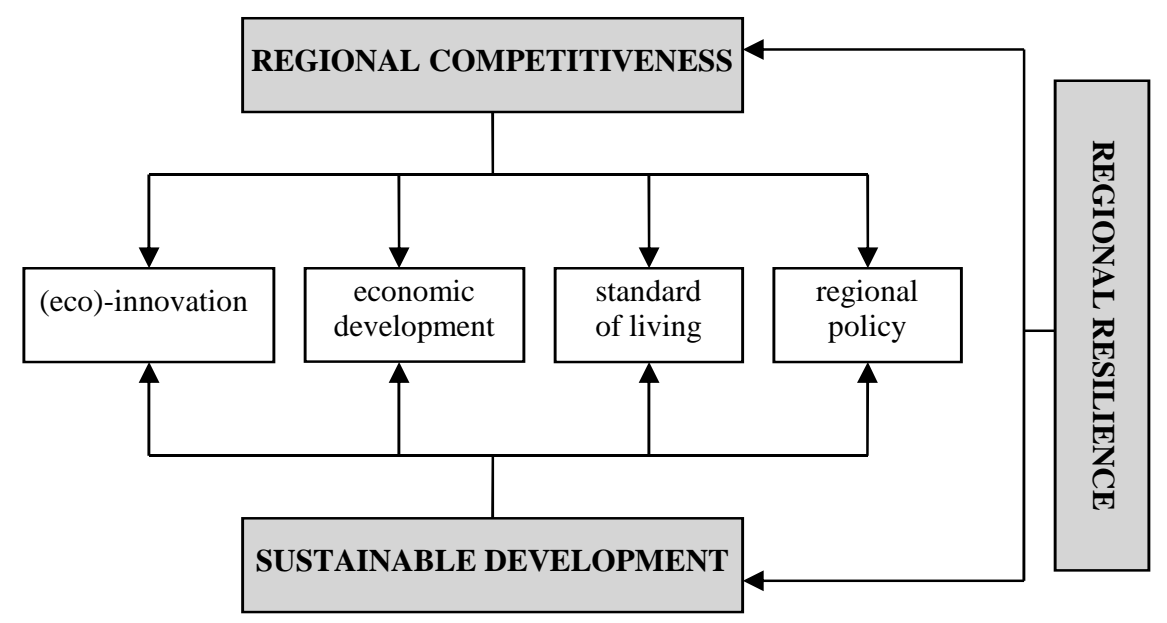

Figure 1. Sustainable development and regional competitiveness - common elements Source: own compilation.

${ }^{37}$ K.A. Foster, A case study approach to understanding regional resilience, Working Paper 2007-08, Berkeley 2006, p. 14; R. Hudson, Resilient regions in an uncertain world: wishful thinking or a practical reality?, "Cambridge Journal of Regions, Economy and Society" 2010, 3(1), p. 12, 22; S. Dawley, A. Pike, J. Tomaney, Towards the resilient regions?, "Local Economy" 2010, 25(8), p. 653; J. Simmie, R. Martin, The economic resilience of regions: Towards an evolutionary approach, "Cambridge Journal of Regions, Economy and Society" 2010, 3, p. $28,41$.

${ }^{38}$ R. Hudson, Resilient regions..., p. 22.

${ }^{39}$ J. Fisher, K. Rucki, Re-conceptualizing the science of sustainability: a dynamical system approach to understanding the nexus of conflict, development and environment, "Sustainable Development" 2017, 25, pp. 271-272.

${ }^{40} \mathrm{G}$. Bristow, Resilient regions: re-'place'ing regional competitiveness, "Cambridge Journal of Regions, Economy and Society” 2010, 3, pp. 163-165. 
As much as in the assumptions regarding the growth of competitiveness, also sustainability is often linked to economic development, to meeting human needs, to the improve-

ment of the quality of life (broadly defined as social welfare), to employment policy (as an element conducive to improving the quality of life), and the like. However, in this first concept it is assumed that appropriate focus on development is not to lead to the deterioration of the environment with the aim to allow the future generations to be capable of meeting their needs as well. The problem of social justice is not included in the theory of competitiveness, as well as issues related to the protection of the nature and preservation of the environment and its resources ${ }^{41}$.

As mentioned, both in the case of sustainability and competitiveness, the resources are an important element present in the region. This applies both to natural resources, manmade resources (e.g. infrastructure), human resources and social capital. The right combination of them is one of the factors determining the socio-economic development of regional competitiveness. On the other hand, they are also significant as far as the possibility of sustainable development is concerned - for example, it concerns the level of education, adopted system of values and ethical standards (e.g. taking into account the preservation of environment as a value), creativity (which in turn determines innovation), entrepreneurship, ability to work, and social participation. Just natural resources, their quantity and their spatial distribution, are important not only because of the possibility of their economic use but also because they generate other services (utilities), determine the wider quality of life. The environment related principle of reducing the use of non-renewable resources and re-producing renewable resources (at the right pace) adopted in the concept of sustainable development, could also be extended to other resources that are in the region.

\section{CONCLUSIONS}

It seems nowadays that there are two main paths leading to increased social welfare and regional development. One is the sustainable development and the other is the competitiveness. There are many similarities between these two concepts, i.e. striving toward wellbeing, role of local and regional authorities, significance of (eco-) innovation in economic growth.

Similarities between sustainable development and competitiveness at regional level have been used by some scholars to link these two conpcepts in the idea of sustainable competitiveness ${ }^{42}$. It can be assumed that this concept is properly understood in terms of socio-economic development of a region (i.e. in accordance with its advantages and strengths), which will eventually lead to the improvement of the economy, growth in

\footnotetext{
${ }^{41}$ H. Kruk, D. Waldziński, Rozwój zrównoważony..., p. 94.

${ }^{42}$ e.g.: V. Harmaakorpi, T. Uotila, Building regional visionary capability. Futures research in resource-based regional development, "Technological Forecasting \& Social Change" 2006, 73, pp. 780-781; A. Balkytè, M. Tvaronavičienè, Perception of competitiveness..., pp. 356-359; A.V. Rutkauskas, On the sustainability of regional competitiveness development considering risk, "Technological and Economic Development of Economy" 2008, 14(1), pp. 93-94; S. Thore, $\mathrm{R}$. Tarverdyan, The sustainable competitiveness of nations, "Technological Forecasting \& Social Change" 2016, 106, p. 109; M. Urbaniec, Sustainable competitiveness. Opportunities and challanges for Poland's economy, "Ekonomia i Środowisko" 2016, 4, s. 39-40.
} 
productivity of businesses located in this region and to improve the quality of life for its residents in a long time, provided it is adapted to, and it respects, the natural conditions (especially the capacity of the environment).

According to some authors, the idea of sustainable competitiveness will in the future become an obligatory valid concept, which will combine two - for some nowadays conflicting and contradictory - theories ${ }^{43}$.

However one cannot forget ditfferences between these concepts. For instance, the environmental aspect is one of main dimensions (pillars) of sustainable development, while it is not taken into consideration in case of competitiveness. Moreover, the improvement of standard of living, as an aim of competitiveness, is related only to material wellbeing (income's level), whereas the main goal of sustainability is enhancement of quality of life in its all tangible and intangible dimensions. The question of inter- and intra-generation justice - one of principles of sustainable development - is passed over in the concept of competitiveness. Striving for economic growth as encompassed in the regional competitiveness may also include unsustainable use of natural resources and their degradation.

It is also worth mentioning that some scholars wonder if the term sustainability of competitiveness would be more adequate than the sustainable competitiveness ${ }^{44}$. The idea should be taken into further consideration.

\section{REFERENCES}

[1] Adesola S.A., Overcoming the challanges of sustainable development through science and technology education, "Journal of Educational and Social Research" 2012, 2(7): 11-18.

[2] Annoni P., Kozovska K., EU Regional Competitivness Index. RCI 2010, European Commission, Joint Research Centre, European Union, Luxembourg 2010.

[3] Annoni P., Dijkstra L., Gargano N., The EU regional competitiveness index 2016, Working Papers WP 02/2017, European Union 2017.

[4] Ayala-Carcedo F.J., y Gonzáles-Barros M.R., Economic underdevelopment and sustainable development in the world: conditioning factors, problems and opportunities, "Environment, Development and Sustainability” 2005, 7: 95-115.

[5] Balkytė A., Tvaronavičienė M., Perception of competitiveness in the context of sustainable development: Facets of 'sustainable competitiveness, "Journal of Business Economics and Management" 2010, 11 (2): 341-365.

[6] Berumen S.A., An approach to local and regional competitiveness, Cuadernos de Administración Bogotá (Colombia) 2005, 18:29 13-31.

[7] Borghesi S., Vercelli A., Global sustainability. Social and environmental conditions, Palgrave Macmillan, Hampshire-New York 2008.

[8] Borozan Đ., Regional competitiveness: some conceptual issues and policy implications [in:] Interdisciplinary Management Research IV., Eds. D. Barković, B. Runzheimer. Osijek Pforzheim: Faculty of Economics in Osijek, Fachhochschule Pforzheim 2008, 50-63.

[9] Borys T., Jakość życia a systemy wartości [w:] Uwarunkowania jakości życia w społeczeństwie informacyjnym, red. E. Skrzypek, UMSC w Lublinie, Lublin 2007: 213-220.

${ }^{43} \mathrm{G}$. Lapinskiene், The analysis of the relationship between the sustainable development and competitiveness in European countries, "Intelektine Ekonomika. Intellectual Economics" 2011, 5(3), p. 437.

44 A.V. Rutkauskas, On the sustainability of regional..., p. 94. 
[10] Borys T., Typologia jakości życia i pomiar statystyczny, „Wiadomości Statystyczne” 2015, 7: $1-18$.

[11] Brand F., Critical natural capital revisited: Ecological resilience and sustainable development, "Ecological Economics" 2009, 68: 605-612.

[12] Bristow G., Resilient regions: re- 'place'ing regional competitiveness, "Cambridge Journal of Regions, Economy and Society” 2010, 3: 153-167.

[13] Brol R., Innowacyjność regionu w teorii i praktyce [w:] Problemy rozwoju regionalnego, red. R. Brol, A. Raszkowski, Prace Naukowe Uniwersytetu Ekonomicznego we Wrocławiu, Wrocław 2011, 180: 11-25.

[14] Budd L., Hirmis A., Conceptual framework for regional competitiveness, "Regional Studies" 2004, 38(9): 1015-1028.

[15] Christen M., Schmidt S., A formal framework for conceptions of sustainability - a theoretical contribution to the discourse in sustainable development, "Sustainable Development" 2012, 20(6): 400-410.

[16] Christopherson S., Michie J., Tyler P., Regional resilience: theoretical and empirical perspectives, "Cambridge Journal of Regions, Economy and Society" 2010, 3: 3-10.

[17] Costanza R., Fisher B., Ali S., Beer C., Bond L., Boumans R., Danigelis N.L., Dickinson J., Elliot C., Farley J., Elliott Gayer D., MacDonald Glenn L., Hudspeth T., Mahoney D., McCahill L., McIntosh B., Reed B., Abu Turab Rizvi S., Rizzo D.M., Simpatico T., Snapp R., Quality of life: An approach integrating opportunieties, human needs and subjective wellbeing, "Ecological Economics" 2007, 61: 267-276.

[18] Dawley S., Pike A., Tomaney J., Towards the resilient regions?, Local Economy” 2010, 25(8): 650-667.

[19] Dyllick T., Rost Z., Towards true product sustainability, "Journal of Cleaner Production" 2017, 162: 346-360.

[20] Elliott J.A., An introduction to sustainable development, Routledge, Taylor \& Francis Group, London-New York 2013.

[21] Fisher J., Rucki K., Re-conceptualizing the science of sustainability: a dynamical system approach to understanding the nexus of conflict, development and environment, "Sustainable Development" 2017, 25: 267-275.

[22] Foster K.A., A case study approach to understanding regional resilience, Working Paper 2007-08. Berkeley: MacArthur Foundation Research Network on Building Resilient Regions, Institute of Urban and Regional Development, University of California, 2006.

[23] Gibbs D., Ecological modernisation, regional economic development and regional development agencies, "Geoforum” 2000, 31:1 9-19.

[24] Ginsbert-Gebert A., Ekologiczne uwarunkowania społeczno-ekonomicznego rozwoju Polski, Wydawnictwo SGGW-AR, Warszawa 1990.

[25] Godlewska H., Lokalizacja działalności gospodarczej, Wyższa Szkoła Handlu i Finansów Międzynarodowych. Warszawa 2001.

[26] Graymore M.L.M., Sipe N.G., Rickson R.E., Regional sustainability: How useful are current tools of sustainability assessment at the regional scale?, "Ecological Economics" 2008, 67: 362-372.

[27] Gryszel P., 'Inteligentna' specjalizacja a konkurencyjność regionów turystycznych, „Folia Turistica" 2017, 42: 31-53. 
[28] Harmaakorpi V., Uotila T., Building regional visionary capability. Futures research in resource-based regional development, "Technological Forecasting \& Social Change" 73, 2006: 778-792.

[29] Hudson R., Resilient regions in an uncertain world: wishful thinking or a practical reality?, "Cambridge Journal of Regions, Economy and Society" 2010, 3(1): 11-25.

[30] Huovari J., Kangasharju A., Alanen A., Constructing an index for regional competitiveness, "Pellervo Economic Research Institute Working Papers" 2001, 44, Helsinki.

[31] Imran S., Alam K., Beaumont N., Reinterpreting the definition of sustainable development for a more ecocentric reorientation, "Sustainable Development" 2014, 22: 134-144.

[32] Johansson B., Karlsson C., Backman M., Juusola P., The Lisbon Agenda from 2000 to 2010, CESIS Electronic Working Paper Series, Paper No. 106, 2007.

[33] Keiner M., Re-emphasizing sustainable development - the concept of 'evolutionability', "Environment, Development and Sustainability" 2004, 6: 379-392.

[34] Kemp R., Measuring eco-innovation. Research Brief 1, United Nations University 2008.

[35] Klasik A., Strategie konkurencyjne polskich regionów [w:] Nowe kierunki badawcze $w$ regionalistyce. Nowe doświadczenia polityki regionalnej, red. R. Domański, KPZK PAN, Biuletyn, 2003, z. 204: 63-79.

[36] Koszel M., Formy relacji międzygminnych $w$ polskich obszarach metropolitalnych, Acta Universitatis Nicolai Copernici XLIII (3), 2016: 35-51.

[37] Kruk H., Przyrodnicza konkurencyjność regionów, TNOiK, Wydawnictwo „Dom Organizatora", Torun 2010.

[38] Kruk H., Waldziński D., Rozwój zrównoważony i konkurencyjność regionów - rozważania teoretyczne [w:] Problemy rozwoju regionalnego, red. R. Brol. Prace Naukowe UE we Wrocławiu 110, Wrocław 2010: 87-96.

[39] Lapinskiene G., The analysis of the relationship between the sustainable development and competitiveness in European countries, "Intelektinè Ekonomika. Intellectual Economics" 2011, 5(3): 434-444.

[40] Lengyel I., Competitiveness of metropolitan regions in Visengrad counties, "Procedia Social and Behavioral Sciences" 2016, 223: 357-362.

[41] Marczewska M., Źródta i mechanizmy powstawania ekoinnowacji w przedsiębiorstwach dostawcach technologii środowiskowych, Difin, Warszawa 2016.

[42] Mckinney W.J., Hill H.H., Of sustainability and precaution: the logical, epistemological and moral problems of the precautionary principle and their implications for Sustainable Development, "Ethics and the Environment" 2000, 5(1): 77-87.

[43] Mieszajkina E., Ecological entrepreneurship and sustainable development, "Problemy Ekorozwoju - Problems of Sustainable Development” 2016, 12 (1): 163-171.

[44] Moles R., Foley W., Morrissey J., O'Regan B., Practical appraisal of sustainable development - Methodologies for sustainability measurement at settlement level, "Environmental Impact Assessment Review" 2008, 28: 144-165.

[45] Piontek B., Koncepcja rozwoju zrównoważonego i trwałego Polski, Wydawnictwo Naukowe PWN, Warszawa 2002.

[46] Porter M.E., van der Linde C., Green and competitive: ending the stalemate, "Harvard Business Review" 1995, 73(5): 120-134.

[47] Reid A., Miedzinski M., Sectoral innovation watch in Europe. Ecoinnovation, Final report, Systematic Eco-Innovation Report, Europe Innova, Technopolis Group, Brussels 2008. 
[48] Rogall H., Ekonomia zrównoważonego rozwoju. Teoria i praktyka, Poznań: Wydawnictwo Zysk i S-ka, Poznań 2010.

[49] Ručinská S., Paška P., Measuring regional competitiveness, Acta oeconomica cassoviensia 1, 2009 (vol. II, No 1): 4-12.

[50] Rutkauskas A.V., On the sustainability of regional competitiveness development considering risk, "Technological and Economic Development of Economy" 2008, 14(1): 89-99.

[51] Simmie J., Martin R., The economic resilience of regions: Towards an evolutionary approach, "Cambridge Journal of Regions, Economy and Society" 2010, 3: 27-43.

[52] Singhal S., McGreal S., Berry J., An evaluative model for city competitiveness: Application to UK Cities, "Land Use Policy" 2013, 30: 214-222.

[53] Stanaszek O., Badanie jakości życia w Polsce [w:] Gospodarka regionalna w teorii i praktyce, red. E. Sobczak, D. Głuszczuk, M. Obrębalski, Prace Naukowe Uniwersytetu Ekonomicznego we Wrocławiu, Wrocław 2015, 392: 99-108.

[54] Thore S., Tarverdyan R., The sustainable competitiveness of nations, "Technological Forecasting \& Social Change" 2016, 106: 108-114.

[55] Turok I., Cities, regions and competitiveness, „Regional Studies” 2004, 38(9): 1069-1083.

[56] Urbaniec M., Sustainable competitiveness. Opportunities and challanges for Poland's economy, "Ekonomia i Środowisko" 2016, 4: 34-51.

[57] Vrtěnová L., Evaluation of factors of regional competitiveness [in:] Third Central European Conference in Regional Science. International Conference Proceedings. Eds. M. Buček, R. Capell, O. Hudec, P. Nijkamp,Technical University of Košice, Faculty of Economics, Košice 2009, 1404-1412.

[58] Waldziński D., Polityka regionalna $w$ Polsce $w$ procesie przemian kulturowocywilizacyjnych. Zarys problemu, Wydawnictwo UWM w Olsztynie, Olsztyn 2005.

[59] Ziółko, M., Mróz J., Wpływ ekoinnowacyjności na wzrost konkurencyjności przedsiębiorstw, Acta Universitatis Nicolai Copernici, 2015, XLII (1): 73-84.

[60] Woźniak L., Ekoinnowacyjność w gospodarce żywnościowej [w:] Ekoinnowacyjność dziś i jutro - wyzwania, bariery rozwoju oraz instrumenty wsparcia, red. L. Woźniak, J. Strojny, E. Wojnicka, PARP, Warszawa 2010.

\section{PODOBIEŃSTWA MIĘDZY ROZWOJEM ZRÓWNOWAŻONYM A KONKURENCYJNOŚCIĄ REGIONÓW - UJĘCIE TEORETYCZNE}

Rozwój regionalny zależy od wielu uwarunkowań. Współcześnie mówi się z jednej strony o konieczności zwiększania konkurencyjności regionów, z drugiej natomiast o ich rozwoju zrównoważonym. Niektórzy badacze uważają, że dążenie do poprawy konkurencyjności wyklucza rozwój zrównoważony, podczas gdy inni nie podzielają tej opinii. Jednakże wydaje się ważne, aby nie przeciwstawiać sobie tych dwóch koncepcji, ale starać się je połączyć. Ostatnio te dwa podejścia: poprawa konkurencyjności i implementacja założeń rozwoju zrównoważonego do praktyki gospodarczej są łączone w jedno, wspólne pojęcie zrównoważonej konkurencyjności. W artykule zaprezentowano analizę wybranych definicji konkurencyjności regionalnej oraz pojęć łączonych z tą koncepcją, jak i definicji, celów i czynników zrównoważonego rozwoju, aby znaleźć podobieństwa między tymi dwiema koncepcjami, szczególnie w odniesieniu do poziomu regionalnego. Przedstawiono cechy wspólne dla konkurencyjności i rozwoju zrównoważonego. Są to: dążenie do poprawy jakości życia i rozwój gospodarczy (choć w ujęciu konkurencyjności dotyczy to tylko kwestii materialnych),

wprowadzanie innowacji ekologicznych oraz znacząca rola władz lokalnych i regionalnych. Obie 
koncepcje łączą się również z ideą rezyliencji regionów, czyli ich zdolnością do adaptacji do zmian zachodzących $\mathrm{w}$ otoczeniu. Przyjmuje się, że zarówno regiony dążące do zrównoważenia jak i te konkurencyjne muszą być rezylientne.

Artykuł składa się z trzech głównych części. W pierwszej zaprezentowano definicje i pojęcia powiązane z konkurencyjnością regionów. W kolejnej przedstawiono definicje, cele i składowe rozwoju zrównoważonego. Trzecia część zawiera zestawienie podobieństw między konkurencyjnością regionów a ich zrównoważeniem.

Słowa kluczowe: region, rozwój zrównoważony, konkurencyjność, podobieństwa, zrównoważona konkurencyjność.

DOI: 10.7862/rz.2017.mmr.17

Tekst ztożono w redakcji: marzec 2016 r.

Przyjęto do druku: czerwiec 2017 r. 